\title{
Soil Organic Carbon Density Spatial Distribution and Influencing Factors in a Karst Mountainous Basin
}

\author{
Zhenming Zhang ${ }^{1-2}$, Yunchao Zhou ${ }^{1-3 *}$, Shijie Wang ${ }^{3-4}$, Xianfei Huang ${ }^{1-2}$ \\ ${ }^{1}$ Forest Resource and Environment Research Center of Guizhou Province, Guizhou University, \\ Guiyang 550025, China \\ ${ }^{2}$ College of Forestry, Guizhou University, Guiyang 550025, China \\ ${ }^{3}$ Puding Karst Ecosystem Research Station of Guizhou Province, \\ Puding 562100, China \\ ${ }^{4}$ State Key Laboratory of Environmental Geochemistry, Institute of Geochemistry, \\ Chinese Academy of Science, Guiyang 550002, China
}

Received: 3 January 2017

Accepted: 4 March 2017

\begin{abstract}
To illustrate the distribution pattern of soil organic carbon density (SOCD) in a small karst watershed and its main influencing factors, this research quantitatively analyzed the spatial heterogeneity and distribution characteristics of SOCD using 2,755 thoroughly investigated soil profile samples; field point sampling, laboratory determination, and geo-statistical analysis were used, and the major influencing factors of SOCD were analyzed using a principal components analysis. The results indicated that the SOCD decreased gradually with increasing soil depth in the small karst watershed; in particular, the average SOCD was equal to $12.11 \mathrm{~kg} \cdot \mathrm{m}^{-2}$ at a depth of $100 \mathrm{~cm}$, which is higher than the national level. An optimal fitting model for the SOCD in this Basin was a Gaussian model, which showed a moderately strong spatial correlation. A kriging interpolation suggested that the soil carbon density (SOCD) was higher in the eastern region but lower in the southern region, exhibiting an ascending trend from the middle to the exterior. In the small karst watershed, the SOCD at a depth of $100 \mathrm{~cm}$ differs between different vegetation types, different soil utilization types, and different soil types. The soil thickness, rock coverage and altitude were the principal influencing factors on the SOCD in the small karst watershed, among which soil thickness had the largest impact.
\end{abstract}

Keywords: soil organic carbon density, spatial heterogeneity, influencing factors, small watershed, karst

\section{Introduction}

Soil is a complex historical natural body formed under the joint action of parent material, climate, landforms, and

*e-mail: yczhou@gzu.edu.cn many other factors [1]. In one region, soil-forming factors change with the spatial location and cause a difference and diversity in the soil; furthermore, the soil spatial heterogeneity is a result of multiple factors, including physical, chemical, and biological influences. Soil's formation and evolutionary process are very complex [2]. Different soil-forming factors in different regions have 
created various types of soil; even for the same type of soil, there might be differences in certain properties in different spaces and at different times [3]. Soil organic carbon (SOC) is a relatively active component in soil and has high spatial heterogeneity. It contributes to large differences in the accuracy of soil organic carbon density (SOCD) distribution [4]. Many studies have assessed the influencing factors of spatial heterogeneity and the distribution characteristics of SOCD, including the slope gradient, land use, soil type, biogeochemical reactions, and statistical data analysis techniques [5-6]. Often, calculation accuracy is greatly reduced since the spatial heterogeneity of regional SOCD is ignored owing to limitations on sampling density at a global [7] or national [8] scale. At present, in terms of the spatial heterogeneity of SOCD, there are studies of specific regions [9], basins [10], a province, or several provinces [11]. However, the density of SOCD's spatial heterogeneity is correlated with a change in scale, and the research is based on the above three scales, ranging from small- to medium-scale spatial distribution characteristics of soil organic carbon on a continuous spatial scale, which has rarely been reported. The above studies have mainly analyzed the spatial heterogeneity of SOCD in non-karst areas, whereas there is limited research on the SOCD over a continuous space on the same scale.

A karst ecosystem is a unique ecological system with specific geographic and geomorphic conditions, hydrothermal conditions, vegetation site conditions, and soil development conditions that are different from those in non-karst areas. Because of the special geological and climatic conditions, this type of regional environment is characterized by a small capacity, weak anti-jamming capability, low stability, and poor self-adjustment ability [12]. However, the soil environment in karst areas has the basic features of bedrock outcroppings, small soil volume, discontinuous distribution, and complex micro- topography, and the soil develops discontinuously in the shallow layer, represented by disperse distribution and nonuniform thickness, which may bring lots of uncertainty to the calculation of SOCD [13]; therefore, research on the SOCD of different soil layers in a karst area is required for the evaluation of carbon fixation in soils in this area. Due to the unique environment in a karst area, the estimation of carbon density in non-karst areas is not applicable [14]. Increasing numbers of scientists recognize that more studies concerning SOCD at different scales (national or regional) should be conducted to improve and perfect the global SOCD database, and a great number of studies about SOCD at a regional scale have been reported over the past several years [15]. A large number of scholars have found that the spatial heterogeneity of karst SOC is related closely to soil habitat; other scholars have argued that the spatial distribution characteristics of bare rock must be taken into consideration in research on karst SOCD [16]. However, a number of scholars have argued that the consistency of karst soil formation backgrounds determines the spatial continuity of soil attribute changes, and they suggest researching the spatial heterogeneity of the discontinuous soil in this area using geo-statistical analysis [17]. At present, geo-statistical analysis is frequently used for research of soil organic carbon content or other soil attributes, whereas there is still a lack of quantitative and systematic studies on the spatial heterogeneity of SOCD.

Our primary objectives were to research the SOCD in a small karst watershed, as well as to determine the spatial distribution characteristics and influencing factors with geo-statistical analysis with a thorough sample area survey and laboratory analysis, laying a solid foundation for further research into the spatial heterogeneity of soil attributes and the carbon sequestration of these ecosystems. This in-depth study of a karst area and accurate estimation of its carbon pool provide a reference

Table 1. Geographic information of the study area.

\begin{tabular}{|c|c|c|c|}
\hline Items & Chengguan Town & Maguan Town & Baiyan Town \\
\hline Precipitation (mm) & $1,170.9$ & $1,178.8$ & $1,396.9$ \\
\hline Temperature $\left({ }^{\circ} \mathrm{C}\right)$ & 15.3 & 15.2 & 15.1 \\
\hline Frostless season (days) & 301 & 289 & 292 \\
\hline Soil thickness (cm) & $6->100(70.14)^{\mathrm{a}}$ & $6->100(57.36)$ & $5->100(58.76)$ \\
\hline Major vegetation & $\begin{array}{c}\text { Tree species: Cupressus } \\
\text { funebris Endl, Broussonetia } \\
\text { papyrifera, Populus } \\
\text { Adenopoda Maxim } \\
\text { Shrub species: Pyracantha } \\
\text { floruneana, Itea ilicifolia }\end{array}$ & $\begin{array}{l}\text { Tree species: Cupressus } \\
\text { funebris Endl, Broussonetia } \\
\text { papyrifera, Toona sinensis } \\
\text { (A.Juss.) Roem., Celtis sinensis. } \\
\text { Shrub species: Rosa cymosa, } \\
\text { Zanthoxylum bungeanumMaxim }\end{array}$ & $\begin{array}{c}\text { Tree species: Cupressus funebris } \\
\text { Endl, Platycarya longipes, Pyrus } \\
\text { pyrifolia Burm Nakai } \\
\text { Shrub species: Pyracantha } \\
\text { floruneana, Rosa cymosa }\end{array}$ \\
\hline Land use (\%) & $\begin{array}{c}\text { Forest: } 11.84 \\
\text { Bush forest: } 15.67 \\
\text { Cultivated: } 56.75 \\
\text { Unused: } 5.85 \\
\text { Construction: } 9.92\end{array}$ & $\begin{array}{c}\text { Forest: } 14.67 \\
\text { Bush forest: } 22.54 \text { Cultivated: } \\
49.84 \\
\text { Unused: } 7.13 \\
\text { Construction: } 5.82\end{array}$ & $\begin{array}{c}\text { Forest: } 16.24 \\
\text { Bush forest: } 18.33 \text { Cultivated: } \\
54.38 \\
\text { Unused: } 4.91 \\
\text { Construction: } 6.14\end{array}$ \\
\hline
\end{tabular}

Note: "a" is the mean value of soil thickness 
to inform regional sustainable development and to provide accurate estimation of the global soil carbon pool.

\section{Materials and Methods}

\section{Study Region}

The study region $\left(105^{\circ} 40^{\prime} 43^{\prime \prime}-105^{\circ} 48^{\prime} 2^{\prime \prime} \mathrm{E}, 26^{\circ} 12^{\prime} 29^{\prime \prime}-\right.$ $\left.26^{\circ} 17^{\prime} 15^{\prime \prime} \mathrm{N}\right)$ is located in Puding County in the central part of Guizhou Province in southwestern China, including the three towns of Chengguan (CG), Maguan (MG), and Baiyan (BY), and it covers an area of $72 \mathrm{~km}^{2}$. The elevation is between 1,223.4 and 1,567.4 $\mathrm{m}$ above sea level, and the air pressure is between 806.1 and $883.8 \mathrm{hpa}$. There are three major categories of soil: limestone, paddy, and yellow. The vegetation (Table 1) includes cedarwood (Cupressus funebris Endl.), populus adenopoda (Populus Adenopoda Maxim), toona sinensis (Toona sinensis (A. Juss.) Roem.), and Chinese pear (Pyrus pyrifolia Burm Nakai.). The main crops are paddy rice (Oryzasativa Oryzaglaberrima), corn (Zea mays Linn. Sp.), soybean (Glycine $\max$ (Linn.) Merr), and sunflower (Helianthus annuus). There are nine soil types in the study area: yellow clay, rendzina, yellow limestone soil, large loam, small clay, white large loam, white sand, large mud field loam, and yellow clayey soil.

\section{Soil Sampling}

Sampling plots were designed with a grid-based sampling method and a total of 3,180 sampling grids $(150 \mathrm{~m} \times 150 \mathrm{~m})$. The sampling sites were defined as the center of each sampling grid (Fig. 1). 2,755 soil profiles, consisting of 22,057 soil samples, were sampled in the designed sampling grids. A total of 425 designed sampling sites were located in places where sampling could not be carried out, such as in traffic throughways, on tractor roads, in residential housing, industrial parks, streams, and so on. Each profile was divided into 12 soil horizons (0-5 cm, 5-10 cm, 10-15 cm, $15-20 \mathrm{~cm}, 20-30 \mathrm{~cm}$, $30-40 \mathrm{~cm}, 40-50 \mathrm{~cm}, 50-60 \mathrm{~cm}, 60-70 \mathrm{~cm}, 70-80 \mathrm{~cm}$, $80-90 \mathrm{~cm}$, and $90-100 \mathrm{~cm}$ ) if the soil thickness was equal or larger to $95 \mathrm{~cm}$. Otherwise, sampling was carried out to the actual depth. For instance, if a soil profile was $26 \mathrm{~cm}$ in depth, five soil samples were taken $(0-5 \mathrm{~cm}, 5-10 \mathrm{~cm}$, $10-15 \mathrm{~cm}, 15-20 \mathrm{~cm}$, and $20-26 \mathrm{~cm}$ ); if a soil profile was $33 \mathrm{~cm}$ in thickness, five soil samples were taken $(0-5 \mathrm{~cm}$, $5-10 \mathrm{~cm}, 10-15 \mathrm{~cm}, 15-20 \mathrm{~cm}$, and $20-30 \mathrm{~cm}$ ).

Local information for each sampling point along with the soil bulk density, soil thickness, rock coverage, and other indexes were measured at each point and recorded on the spot. The soil samples were air dried, ground, and prepared for the specimen as required by the laboratory; then the SOC content was tested and analyzed. The SOC was determined via a potassium dichromate method. The soil acreage was calculated using geographic information system (GIS) technology and surveying in the field. The bulk density was measured layer by layer from the top to the bottom of the soil profile via a cutting-ring method. The soil thickness was recorded in accordance with the type of ecological niche with an iron stick that was 60 or $120 \mathrm{~cm}$ long, depending on the soil mass at different depths. The bare rock rate was surveyed with a line-transect method. Due to the complex landscape in a karst area, it would be more accurate but less operable if the line transect was too

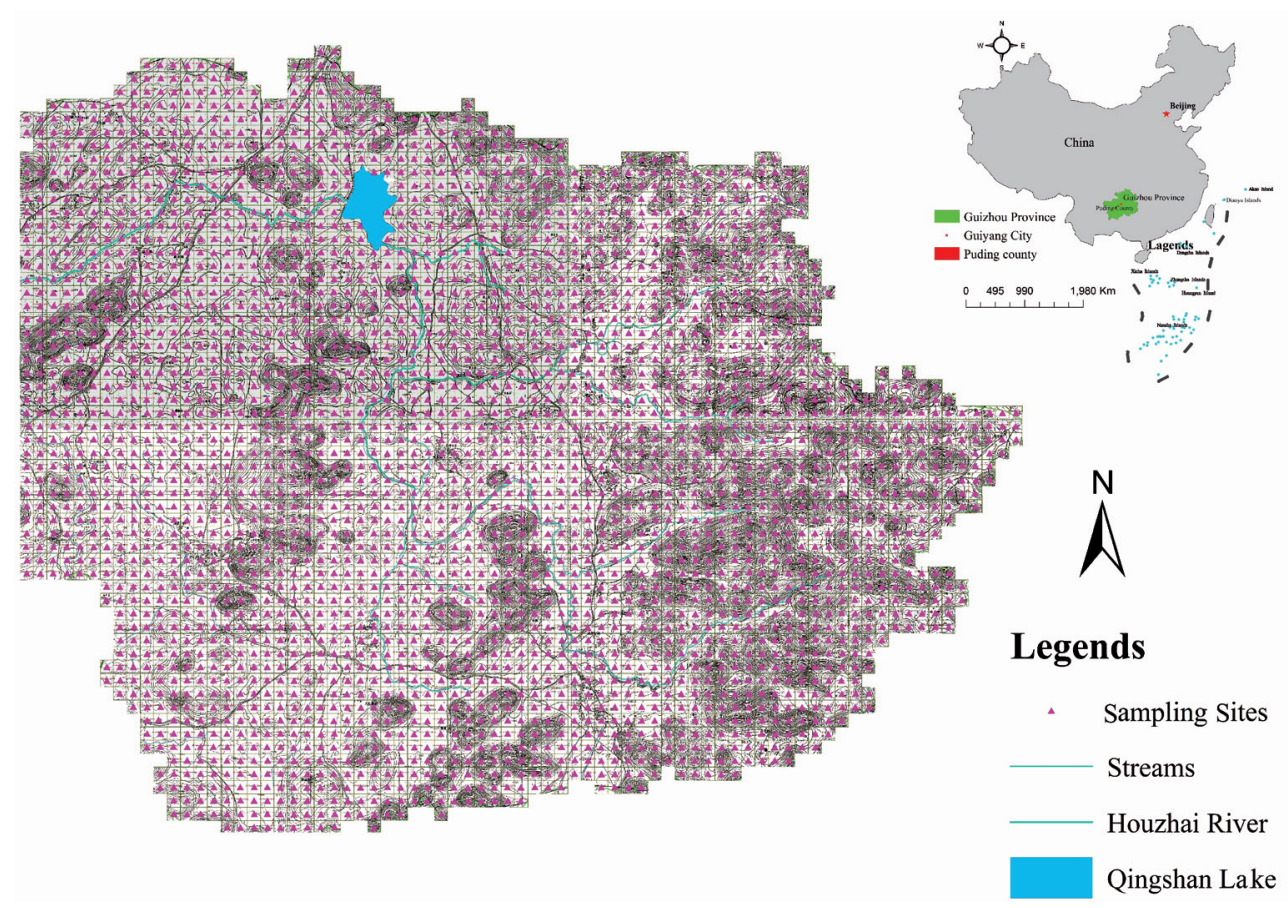

Fig. 1. The location of Houzhai river small watershed and the distribution of sample sites 
long. Therefore, the length of the line transect was set at $10 \mathrm{~m}$, and the grid cells with rock coverage were surveyed via tape measure.

\section{Calculations and Statistical Analysis}

The soil bulk density (SBD) was determined on the spot (cylindrical core method). For each layer of all soil profiles, $181.58 \mathrm{~cm}^{3}$ of soil was sampled with a cutting ring $(\mathrm{r}=3.4 \mathrm{~cm}, \mathrm{~h}=5 \mathrm{~cm})$ and the fresh weight was obtained with a portable balance. Approximately $5 \mathrm{~g}$ of soil from each layer were collected into an aluminum cup whose weight had been determined previously. Three milliliters of alcohol (95\%) was added and lit (repeated three times), and the weight was taken pre- and post-calcination. The SBD was calculated using the following equation:

$$
S B D=\frac{\left(W_{c r+s}-W_{c r}\right) \times\left(W_{p o s t}-W_{c u p}\right)}{\left(W_{p r e}-W_{c u p}\right) \times 181.58}
$$

The SBD represents the soil bulk density $\left(\mathrm{g} \cdot \mathrm{cm}^{-3}\right), W_{c r}$ is the weight of the cutting ring (g), $W_{c r+s}$ is the weight of the cutting ring with fresh soil $(\mathrm{g}), W_{c u p}{ }^{c+s}$ is the weight of the aluminum cup (g), $W_{\text {pre }}$ and $W_{\text {post }}$ are the pre- and postcalcination weights of the aluminum cup with soil (g), and 181.58 is the volume of the cutting ring $\left(\mathrm{cm}^{3}\right)$.

Soil organic carbon density is a certain depth of soil organic carbon storage in the unit area. The calculation formula of organic carbon density $\left(\mathrm{kg} \cdot \mathrm{m}^{-2}\right)$ in a soil layer is as follows [18]:

$$
S O C D_{j}=C_{j} \times D_{j} \times E_{j} \times\left(1-G_{j}\right) \times\left(1-O_{j}\right) / 100
$$

... where $\mathrm{C}_{j}$ MERGEFORMAT is the SOC content in the layer of soil genus $j\left(\mathrm{~g} \cdot \mathrm{kg}^{-1}\right), \mathrm{D}_{j}$ is the soil bulk density of the layer of soil genus $j\left(\mathrm{~g} \cdot \mathrm{cm}^{-3}\right), \mathrm{E}_{j}$ is soil thickness of the layer of soil genus $j(\mathrm{~cm}), \mathrm{G}_{j}$ is the volume percentage of gravel that is larger than $2 \mathrm{~mm}$ of soil genus $j$, and $\mathrm{O}_{j}$ is the bare rock rate in the sampling area of soil genus $j(\%)$.

A semi-variance function (h) was used to describe the spatial heterogeneity of the soil properties. The semi variance function was used to obtain the variation of the semi-variance function value with an increase in the distance of the sample; the scatter plots were fitted with a Gaussian model and other theoretical models. When the soil properties met a two-order stationary assumption and the intrinsic hypothesis and when the sample size was large enough, the semi-variance theory variation function (h) formula was used. The semivariance $(r(h))$ is as follows [19]:

$$
r(h)=\frac{1}{2 N(h)} \sum_{i=1}^{N(h)}\left[Z\left(x_{i}\right)-Z\left(x_{i}+h\right)\right]^{2}
$$

...where $\mathrm{Z}$ is the measured soil property, $\mathrm{x}$ is the sample location, and $N(h)$ is the number of pairs of locations separated by a lag distance $h$. The semivariogram expresses the relationship between the semivariance and the lag distance (h). It typically increases from a value at $h=0$ (identified as the nugget) to a maximum value (identified as the sill). The SOCD of the spatial distribution pattern was determined using a kriging interpolation method with a spatial interpolation grid.

\section{Data Analysis}

First, with different levels of soil organic carbon density data values for quality control, the numerical calculations of the distribution with the four percentile method was used to determine the extreme limit and extreme limit values to calculate the maximum and minimum value, mean value, standard deviation, and coefficient of variation. Second, a spatial autocorrelation analysis was conducted using the semi-variance function variables, which must meet the normal distribution data of non-normal distribution; this will cause proportional effects on the variance function and reduce the estimation precision.

Using SPSS 18.0 statistical software for a single factor analysis of variance (ANOVA), a Pearson correlation analysis and stepwise regression analysis were conducted. A semi-variogram model, fitted with GS+ software, was used for ordinary kriging interpolation in ArcGIS 9.3 software, rendering an organic carbon density spatial distribution map.

\section{Results}

\section{Descriptive Statistical Analysis of the SOCD in Different Layers}

This paper conducted a statistical calculation of the valid data on a 12-layer SOCD based on data quality control and effectiveness analysis, undertaking descriptive statistical analysis on the SOCD of permanent plots in different layers in the small karst watershed (Table 2). Since lots of sample plots in karst areas have the basic features of bedrock outcroppings, small soil volume, discontinuous distribution, and complex micro-topography, the soil develops discontinuously in the shallow layer, which features non-uniform thickness, and different sizes of samples were taken from the soil at different depths; meanwhile, the sample size decreased gradually. The total average organic carbon density of all soil profiles was $1.21 \pm 0.65 \mathrm{~kg} \cdot \mathrm{m}^{-2}$, the maximum was $12.47 \mathrm{~kg} \cdot \mathrm{m}^{-2}$, and the minimum was $0.11 \mathrm{~kg} \cdot \mathrm{m}^{-2}$. The mean SOCD in each layer reached its maximum at a depth of $20-30 \mathrm{~cm}$, equal to $1.5 \mathrm{~kg} \cdot \mathrm{m}^{-2}$. On the whole, the SOCD in each layer decreased gradually with increasing soil depth. The $C_{v}$ of the SOCD, in general, was $C_{v}<10 \%$, and there was weak variability; when the $C_{v}$ was between $10 \%$ and $100 \%$, there was moderate variability; and when the $C_{v}>100 \%$, there was strong variability [20]. The spatial variation of the SOCD in each layer was moderate, and the variation coefficient of the SOCD in each layer first increased and 
Table 2. Statistical results of soil organic carbon density.

\begin{tabular}{|c|c|c|c|c|c|c|}
\hline $\begin{array}{c}\text { Depth of soil layer } \\
(\mathrm{cm})\end{array}$ & $\mathrm{N}$ & $\begin{array}{c}\text { Maximum } \\
\left(\mathrm{kg} \cdot \mathrm{m}^{-2}\right)\end{array}$ & $\begin{array}{c}\text { Minimum } \\
\left(\mathrm{kg} \cdot \mathrm{m}^{-2}\right)\end{array}$ & $\begin{array}{c}\text { Mean } \\
\left(\mathrm{kg} \cdot \mathrm{m}^{-2}\right)\end{array}$ & $\begin{array}{c}\text { Standard } \\
\text { Deviation }\end{array}$ & $\begin{array}{c}\text { Coefficient of variation } \\
(\%)\end{array}$ \\
\hline $0-10$ & 2,755 & 5.27 & 0.11 & 1.25 & 0.61 & 48.80 \\
\hline $10-20$ & 2,595 & 4.64 & 0.12 & 1.05 & 0.59 & 56.19 \\
\hline $20-30$ & 2,397 & 8.37 & 0.12 & 1.50 & 0.95 & 63.32 \\
\hline $30-40$ & 2,049 & 8.63 & 0.11 & 1.21 & 0.80 & 66.32 \\
\hline $40-50$ & 1,765 & 6.27 & 0.11 & 1.03 & 0.69 & 66.91 \\
\hline $50-60$ & 1,554 & 12.47 & 0.11 & 0.92 & 0.71 & 77.55 \\
\hline $60-70$ & 1,379 & 7.73 & 0.11 & 0.84 & 0.65 & 77.91 \\
\hline $70-80$ & 1,233 & 7.49 & 0.11 & 0.76 & 0.62 & 80.56 \\
\hline $80-90$ & 1,081 & 5.19 & 0.11 & 0.71 & 0.56 & 79.45 \\
\hline $90-100$ & 942 & 4.95 & 0.11 & 0.67 & 0.53 & 78.95 \\
\hline
\end{tabular}

then decreased with increasing soil depth. The variation coefficient of the SOCD reached its maximum at a depth of $70-80 \mathrm{~cm}$.

\section{Geo-Statistical Analysis of the SOCD in Different Layers}

See Table 3 for the semi-variance model and relevant parameters of the SOCD in the small karst watershed. There was a difference in the nugget $\mathrm{C}_{0}$ between the different layers, and the nugget $\mathrm{C}_{0}$ at a depth of 90-100 $\mathrm{cm}$ was minimum. Soil heterogeneity was determined by a combined action of structural factors and random factors, and the nugget $\mathrm{C}_{0}$ could help identify the structural factors and random factors that affected soil heterogeneity. The value of $\mathrm{C}_{0}$ indicated the degree of variation in the soil. The higher the value of $\mathrm{C}_{0}$, the higher the degree of variation caused by the random part; on the contrary, the variation was mainly caused by structural influences [21-22]. If the value of $\mathrm{C}_{0}$ was smaller than $25 \%$, the variable had an intense spatial correlation, between $25 \%$ and $75 \%$, and the variable exhibited medium spatial correlation; if the value was larger than $75 \%$, the variable had weak correlation. The nugget $\mathrm{C}_{0}$ of the SOCD in each layer in the small karst watershed was relatively high, and the nugget $\mathrm{C}_{0}$ of each layer occupied a large proportion of the sill $\mathrm{C}_{0}+\mathrm{C}_{1}$, which was greater than $70 \%$, suggesting that random factors had a major effect on the soil heterogeneity in the small karst watershed.

In the semi-variance model, the range referred to the distance that the variation function had to travel to reach the sill, which reflects the size of the autocorrelation range of soil spatial heterogeneity. As a mean variation scale of soil spatial heterogeneity in space, this can help forecast the approximate range of soil spatial heterogeneity. The step length and range in the small karst watershed were $2,726.3 \mathrm{~m}$ to $3,556.0 \mathrm{~m}$, and the range of $0-100 \mathrm{~cm}$ exhibited an increasing trend first and then a decreasing

Table 3. Semivariogram theoretical models and parameters for different layers of soil organic carbon density.

\begin{tabular}{|c|c|c|c|c|c|c|c|c|}
\hline Soil layer $(\mathrm{cm})$ & Model type & $\begin{array}{c}\text { Nugget } \\
\left(\mathrm{C}_{0}\right)\end{array}$ & $\begin{array}{c}\text { Sill } \\
\left(\mathrm{C}_{0}+\mathrm{C}_{1}\right)\end{array}$ & $\mathrm{C}_{0} /\left(\mathrm{C}_{0}+\mathrm{C}_{1}\right)$ & $\begin{array}{c}\text { Partial base } \\
\text { value }\left(\mathrm{C}_{1}\right)\end{array}$ & $\begin{array}{c}\text { Range } \\
(\mathrm{m})\end{array}$ & $\mathrm{R}^{2}$ & RMSE \\
\hline $0-10$ & Gaussian model & 0.31 & 0.33 & 0.94 & 0.04 & $2,811.6$ & 0.96 & 0.92 \\
\hline $10-20$ & Gaussian model & 0.27 & 0.30 & 0.90 & 0.04 & $2,726.3$ & 0.96 & 0.62 \\
\hline $20-30$ & Gaussian model & 0.80 & 0.87 & 0.92 & 0.07 & 3,556 & 0.84 & 0.76 \\
\hline $30-40$ & Gaussian model & 0.55 & 0.60 & 0.92 & 0.06 & $3,431.8$ & 0.91 & 0.81 \\
\hline $40-50$ & Gaussian model & 0.39 & 0.43 & 0.91 & 0.04 & $3,268.9$ & 0.97 & 0.67 \\
\hline $50-60$ & Gaussian model & 0.41 & 0.50 & 0.82 & 0.09 & $2,853.1$ & 0.93 & 0.82 \\
\hline $60-70$ & Gaussian model & 0.36 & 0.41 & 0.88 & 0.05 & 3,556 & 0.87 & 0.91 \\
\hline $70-80$ & Gaussian model & 0.33 & 0.40 & 0.83 & 0.06 & 3,556 & 0.78 & 0.76 \\
\hline $80-90$ & Gaussian model & 0.23 & 0.30 & 0.77 & 0.07 & 3,556 & 0.81 & 0.61 \\
\hline $90-100$ & Gaussian model & 0.19 & 0.27 & 0.70 & 0.08 & 3,556 & 0.89 & 0.81 \\
\hline
\end{tabular}


a)

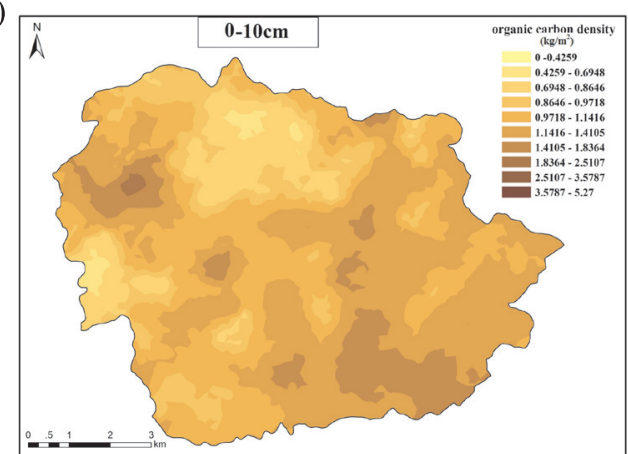

b)



c)

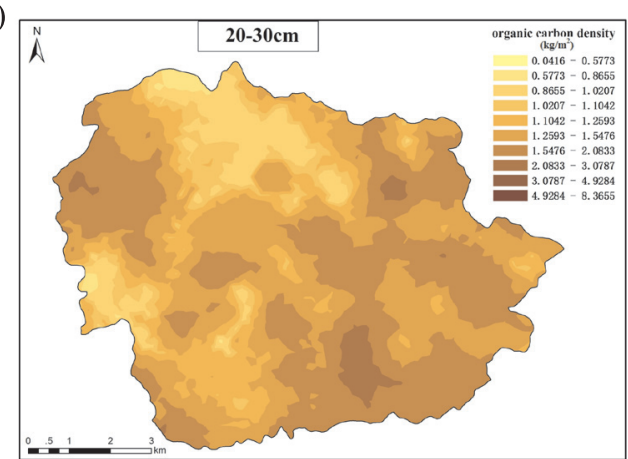

d)

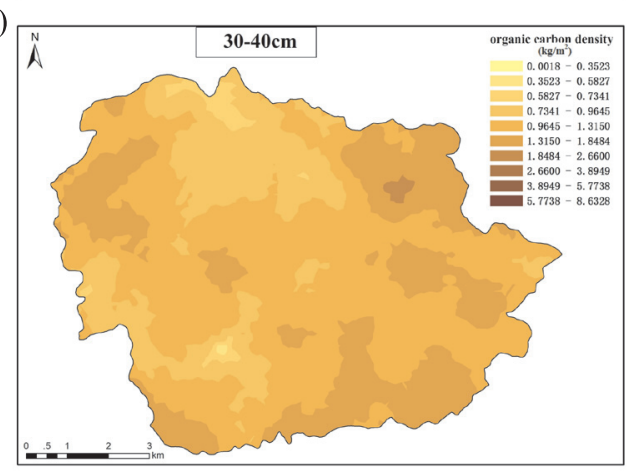

e)

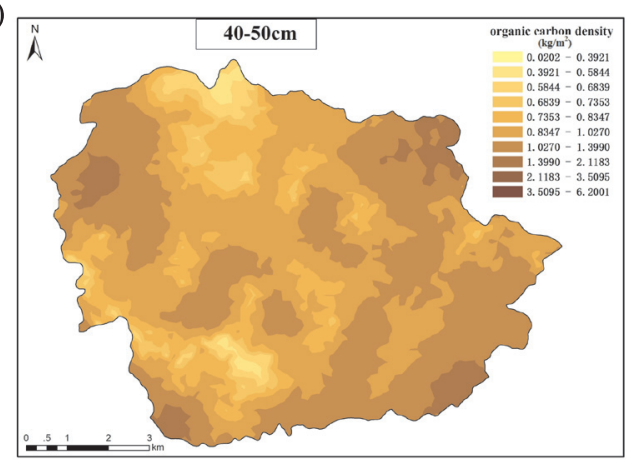

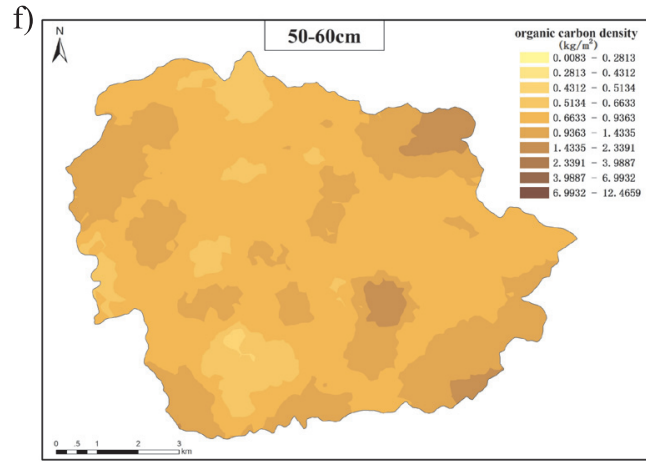

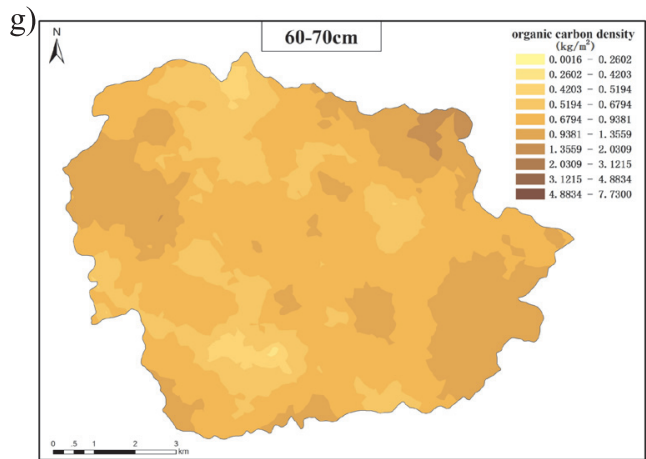

h)

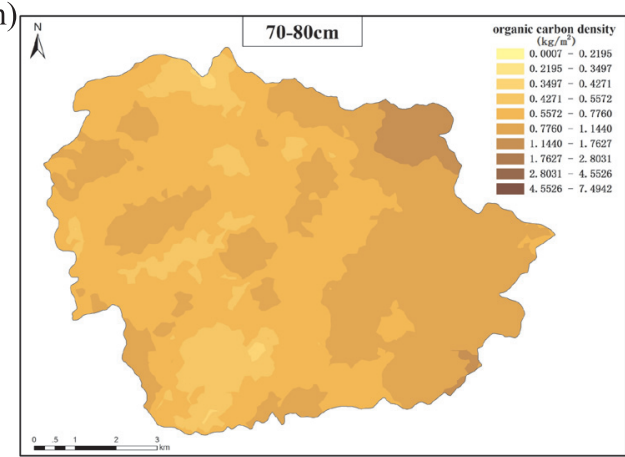

i)

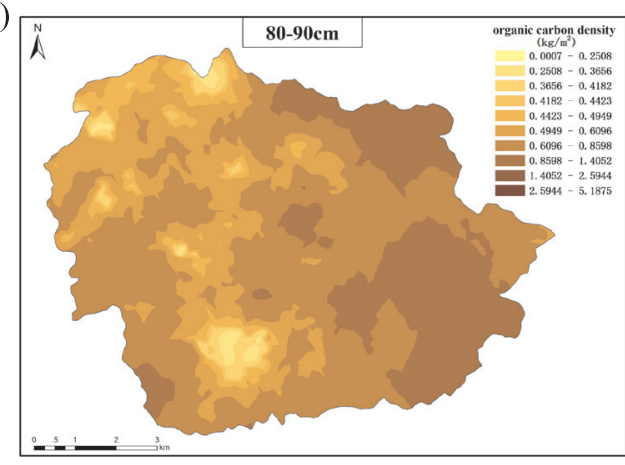

j)

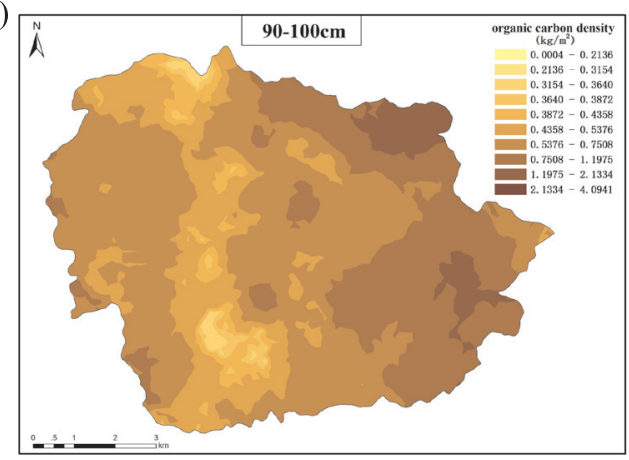

Fig. 2. Spatial distribution of different layers of soil organic carbon density: a) $(0-10 \mathrm{~cm}), \mathrm{b})(10-20 \mathrm{~cm})$, c) $(20-30 \mathrm{~cm})$, d) $(30-40 \mathrm{~cm})$, e) $(40-50 \mathrm{~cm})$, f) $(50-60 \mathrm{~cm})$, g) $(60-70 \mathrm{~cm})$, h) $(70-80 \mathrm{~cm})$, i) $(80-90 \mathrm{~cm})$, j) $(90-100 \mathrm{~cm})$. 
trend, finally becoming stable, and the step lengths of $60-100 \mathrm{~cm}$ were all $3,556 \mathrm{~m}$. In detail, if range was less than the delay distance $(9.6 \mathrm{~m})$, this suggested that there were smaller variations in the sampling intervals; if range was greater than the delay distance $(9.6 \mathrm{~m})$, this suggests that regional factors had bigger impacts on it. As shown in Table 3, the range of the SOCD in each layer in the small karst watershed was greater than the delay distance, suggesting that there was a correlation in the SOCD between the soil layers in the small karst watershed. This had something to do with the fact that the SOCD in each layer in the small karst watershed was greatly affected by the parent material, landform, soil type, and other relevant natural conditions; therefore, there was a correlation in SOCD between the soil layers in the small karst watershed on a relatively large scale. This corresponded to what was reflected by the nugget $C_{0}$ in that structural factors had a major effect on soil heterogeneity of the small karst watershed.

\section{Spatial Distribution Pattern of the SOCD in Different Layers}

A spatial distribution map (Fig. 2) could be made for the SOCD in different layers based on an interpolation calculation of the SCOD data measured with a kriging interpolation method. This map could display the differences in the spatial distribution patterns of SCOD between different layers more clearly. There was a complex spatial variation in the SOCD due to the common effects of geographic location, climatic conditions, soil type, vegetation type, and soil utilization type. In this basin, the SOCD in each layer was generally higher in the eastern region and lower in the western region. The SOCD was dispersed in the surface soil, and there was merely spatial variation in the surface SOCD on a small scale. It decreased gradually from east to west, with small highvalue and low-value areas concentrated in the eastern and western research areas, respectively. In detail, the zones in which the SOCD was less than $0.39 \mathrm{~kg} \cdot \mathrm{m}^{-2}$ comprised $20 \%$ of the total area. As the soil depth increased, the SOCD decreased progressively layer by layer, indicating an insignificant difference in the low value range, but the area of the zones in which the SOCD was less than 0.056$0.39 \mathrm{~kg} \cdot \mathrm{m}^{-2}$ in the three layers decreased layer by layer. The research results indicate that there was a similarity in the spatial distribution characteristics of the SOCD between the 12 layers, and the density was low in the middle, high in the west, higher in the east, and the lowest in the south.

\section{Influencing Factors on the SOCD in the Small Karst Watershed}

\section{Vegetation Factor}

The SOC in the small karst watershed (Fig. 3) came mainly from two sources: plant litter aboveground and organic matter from the plant roots underground. Different plant community compositions and structures had different

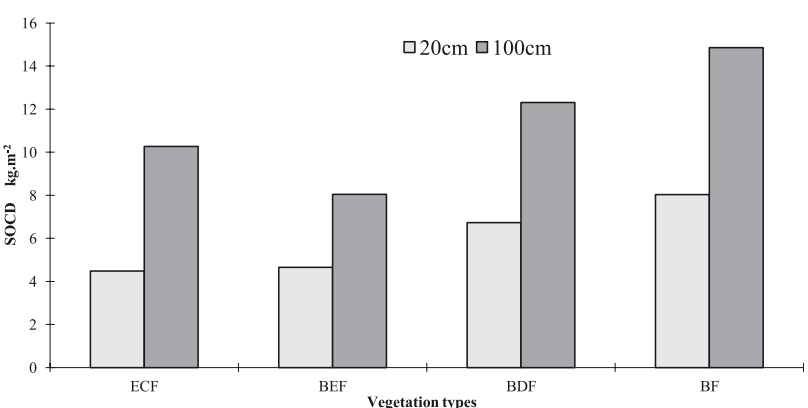

Fig. 3. Spatial distribution of soil organic carbon density under non vegetation type.

Notes: ECF $=$ evergreen coniferous forest, $\mathrm{BEF}=$ Broadleaved evergreen forests, $\mathrm{BDF}=$ broadleaved deciduous forest, $\mathrm{BF}=$ bush forest

capacities for the input and interception of organic carbon. The major types of forest vegetation in the small karst watershed included evergreen coniferous forest, broadleaved evergreen forest, broadleaved deciduous forest, and bush forest. According to the comparison of the SOCD between the major types of forest vegetation in the small karst watershed, the most dense soil carbon at a depth of $20 \mathrm{~cm}$ was identified bush forest $\left(8.04 \mathrm{~kg} \cdot \mathrm{m}^{-2}\right)$, followed by broadleaved deciduous forest $\left(6.74 \mathrm{~kg} \cdot \mathrm{m}^{-2}\right)$, broadleaved evergreen forest $\left(4.66 \mathrm{~kg} \cdot \mathrm{m}^{-2}\right)$, and evergreen coniferous forest $\left(4.49 \mathrm{~kg} \cdot \mathrm{m}^{-2}\right)$; the most dense soil carbon at a depth of $100 \mathrm{~cm}$ was identified in bush forest $\left(14.86 \mathrm{~kg} \cdot \mathrm{m}^{-2}\right)$, followed by broadleaved deciduous forest $\left(12.32 \mathrm{~kg} \cdot \mathrm{m}^{-2}\right)$, evergreen coniferous forest $\left(10.28 \mathrm{~kg} \cdot \mathrm{m}^{-2}\right)$ and broad-leaved evergreen forest $\left(8.05 \mathrm{~kg} \cdot \mathrm{m}^{-2}\right)$. The SOCD in the bush forest was obviously higher than that in other types of forest vegetation.

\section{Land Use Pattern Factors}

Fig. 4 provides the mean SOCD in the primary utilized lands in the small karst watershed. Since there was a difference in soil organic carbon content (SOCC) between the different types of land, there was a difference in the SOCD. In the vertical distribution, the SOCD and SOCC under five soil utilization types were lower at a depth of $20 \mathrm{~cm}$ than at a depth of $100 \mathrm{~cm}$. In the horizontal distribution, due to the high organic carbon content and

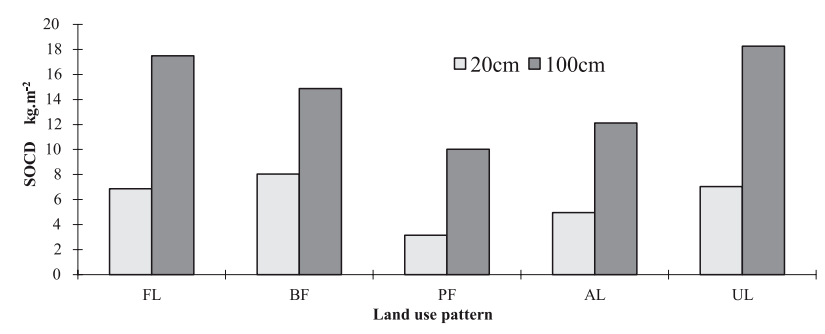

Fig. 4. Spatial distribution of soil organic carbon density under land use patterns.

Notes: $\mathrm{FL}=$ forestland, $\mathrm{BF}=$ bush forest, $\mathrm{PF}=$ paddy field, $\mathrm{AL}=$ arid land, $\mathrm{UL}=$ unused land. 
soil bulk density in the forestland, shrubby grassland and unused land, the SOCD in each layer in the these lands was higher than in the paddy fields and on arid lands. The SOCD at a depth of $20 \mathrm{~cm}$ changed over a range from 3.41 to $8.04 \mathrm{~kg} \cdot \mathrm{m}^{-2}$; the SOCD was highest in shrubby grassland $\left(8.04 \mathrm{~kg} \cdot \mathrm{m}^{-2}\right)$, followed by unused land $\left(7.04 \mathrm{~kg} \cdot \mathrm{m}^{-2}\right)$, forestland $\left(6.87 \mathrm{~kg} \cdot \mathrm{m}^{-2}\right)$, arid land $\left(4.96 \mathrm{~kg} \cdot \mathrm{m}^{-2}\right)$, and paddy fields $\left(3.41 \mathrm{~kg} \cdot \mathrm{m}^{-2}\right)$; the SOCD at a depth of $100 \mathrm{~cm}$ changed over a range from 10.01 to $18.25 \mathrm{~kg} \cdot \mathrm{m}^{-2}$, the SOCD was highest under unused land, followed by forestland, shrubby grassland, arid land, and paddy fields. The SOCD of all types of land was $72.28 \mathrm{~kg} \cdot \mathrm{m}^{-2}$, and the SOCD of the soil at a depth of 0-20 cm accounted for approximately the whole SOCD.

\section{Edaphic Factors}

As shown in Table 4, there was a difference in SOCD between the nine types of soil. The SOCD at a depth of $20 \mathrm{~cm}$ changed over a range from 3.31 to $5.61 \mathrm{~kg} \cdot \mathrm{m}^{-2}$, and it was the highest in black limestone soil, followed by yellow limestone soil, white sandy soil, white big mud soil, small mud soil, big mud field, big mud soil, yellow clayey soil, and yellow soil; the SOCD at a depth of $100 \mathrm{~cm}$ changed over a range from 9.11 to $14.46 \mathrm{~kg} \cdot \mathrm{m}^{-2}$, and the SOCD was highest in white big mud soil, followed by big mud soil, big mud field, small mud soil, yellow soil, yellow limestone soil, yellow mud field, white sandy soil, and black limestone soil. For the whole soil, the SOCD of all 10-cm-thick soil layers belonging to different geneses decreased gradually with increasing soil depth, and gradually stabilized in the deep soil. The maximum SOCD of each 10-cm-thick soil layer was 7.9 times as high as the minimum SOCD. The SOCD at a depth of less than $100 \mathrm{~cm}$ changed over a range from 6.27 to $13.19 \mathrm{~kg} \cdot \mathrm{m}^{-2}$, whereas the mean SOCD of $87-\mathrm{cm}$-thick soil nationwide equaled $10.53 \mathrm{~kg} \cdot \mathrm{m}^{-2}$. Due to the large spatial variation in soil thickness in karst areas, a comparison was made between the $10-\mathrm{cm}$-thick SOCD and the national level. The mean SOCD of the 10-cm-thick soil in the small karst watershed equaled $2.09 \mathrm{~kg} \cdot \mathrm{m}^{-2}$, whereas the mean SOCD of the $10-\mathrm{cm}$-thick soil nationwide equaled $1.21 \mathrm{~kg} \cdot \mathrm{m}^{-2}$, suggesting that the SOCD in the karst areas were 1.7 times as high as the national level.

\section{Other Environmental Factors}

See Table 5 for the correlation analysis between the SOCD and environmental factors in the small karst watershed. The results indicate that the SOCD was significantly correlated with altitude, soil thickness, gravel content, slope, and rock coverage $(p<0.01)$. Because of the strong correlation among the environmental factors and their interactions, the contribution of environmental factors to SOCD could not be independently determined. Therefore, a principal component analysis (PCA) was used to extract the main factor that influenced the SOCD.

\section{The Dominant Factor Influencing the SOCD in the Small Karst Watershed}

The results (Table 6) indicated that the cumulative variance contribution of the first, second, and third principal components of environmental factors on the SOCD could reach $88.97 \%$ in the small karst watershed. This reflected most of the information that those factors affected in the SOCD. The first principal component was mainly determined by the slope position, altitude, slope gradient, and rock coverage, whose variables were $0.91,-0.92$, -0.93 , and -0.96 , respectively. Its variance contribution was $45.72 \%$. The second principal component was mainly determined by soil thickness and gravel content, whose payloads were 0.92 and -0.91 , respectively. Its variance contribution was $28.29 \%$. The third principal component was decided by vegetation, whose payload was 0.93 . Its variance contribution was $15.96 \%$.

Table 4. Statistics of SOC density of different Soil types $\left(\mathrm{kg} \cdot \mathrm{m}^{-2}\right)$.

\begin{tabular}{|c|c|c|c|c|c|c|c|c|c|}
\hline & & \multicolumn{5}{|c|}{$20 \mathrm{~cm}$} & \multicolumn{4}{|c|}{$100 \mathrm{~cm}$} \\
\hline Soil type & $\mathrm{N}$ & Range & Mean & Standard Dev. & CV & Range & Mean & Standard Dev. & CV \\
\hline RD & 613 & $0.22-29.54$ & 4.46 & 2.81 & 63.00 & $0.29-35.23$ & 6.29 & 5.01 & 79.65 \\
\hline YL & 397 & $0.43-16.14$ & 4.33 & 2.07 & 47.81 & $0.51-31.13$ & 7.56 & 4.69 & 62.04 \\
\hline YC & 457 & $0.08-9.40$ & 3.31 & 1.41 & 42.60 & $0.09-33.84$ & 8.68 & 4.69 & 54.03 \\
\hline YCL & 304 & $0.66-10.16$ & 5.01 & 1.82 & 36.33 & $1.29-26.65$ & 10.82 & 4.31 & 39.83 \\
\hline LU & 185 & $1.71-11.57$ & 5.61 & 1.76 & 31.37 & $2.26-44.66$ & 13.19 & 6.02 & 45.64 \\
\hline LL & 129 & $0.96-10.08$ & 4.35 & 1.65 & 37.93 & $1.53-29.93$ & 10.38 & 5.27 & 50.77 \\
\hline WL & 125 & $0.57-10.11$ & 3.96 & 1.86 & 46.97 & $0.92-29.92$ & 7.91 & 5.82 & 73.58 \\
\hline SC & 439 & $0.42-10.54$ & 4.11 & 1.65 & 40.15 & $0.58-24.78$ & 8.34 & 3.34 & 40.05 \\
\hline WS & 106 & $0.09-10.42$ & 4.09 & 2.01 & 49.14 & $0.09-20.19$ & 6.27 & 4.32 & 68.90 \\
\hline
\end{tabular}

Notes: $\mathrm{RD}=$ rendzina, $\mathrm{YL}=$ yellow lime soil, $\mathrm{YC}=$ yellow clay, $\mathrm{YCL}=$ yellow clayey soil, $\mathrm{LU}=$ large mud field loam, $\mathrm{LL}=$ large loam, $\mathrm{WL}=$ white large loam, $\mathrm{SC}=$ small clay, $\mathrm{WS}=$ white sand 




Therefore, the slope position, altitude, slope gradient, and rock coverage could be treated as the main indicators of the first principal component, which was the main factor influencing the SOCD in the small karst watershed. These could be explained as topographic parameters. The soil bulk density and content of gravel were treated as the main indicators of the second principal component. They could be explained as the correlation factor for soil formation. The vegetation was regarded as the main indicator of the third principal component, which was treated as the vegetation factor. To reveal the contribution of environmental factors on the SOCD, a stepwise regression analysis was used to select the principal component index, including the content of gravel, altitude, slope position, soil thickness, slope gradient, rock coverage, and vegetation, and the multiple linear regression equation between the density of the SOCD (dependent variables) and environmental factors (independent variables) was established as follows:

$$
\begin{gathered}
S O C D=1.63 D+7.31 L+5.31 \mathrm{E}+0.72 \mathrm{~A} \\
-1031.29\left(\mathrm{R}^{2}=0.54, \mathrm{p}<0.001\right)
\end{gathered}
$$

...where $S O C D$ is the soil organic carbon density $\left(\mathrm{kg} \cdot \mathrm{m}^{-2}\right), \mathrm{D}$ is soil thickness $(\mathrm{cm}), \mathrm{L}$ is rock coverage (\%), $\mathrm{E}$ is the vegetation type, and $\mathrm{A}$ is the elevation (m). Among these, the soil thickness was most closely related to the SOCD $(\beta=0.52)$, followed by rock coverage $(\beta=0.24)$, vegetation type $(\beta=0.18)$, and elevation $(\beta=0.12)$. Above all, the SOCD was comprehensively affected by different environmental factors in the small karst watershed.

Table 6. PCA on influence factor of SOCD.

\begin{tabular}{|c|c|c|c|}
\hline Influence factor & $\begin{array}{c}\text { First } \\
\text { component }\end{array}$ & $\begin{array}{c}\text { Second } \\
\text { component }\end{array}$ & $\begin{array}{c}\text { Third } \\
\text { component }\end{array}$ \\
\hline Soil bulk density & 0.64 & 0.83 & 0.32 \\
\hline Parent material & -0.46 & -0.32 & 0.28 \\
\hline Vegetation & 0.21 & 0.32 & 0.93 \\
\hline Slope position & 0.91 & 0.42 & 0.45 \\
\hline Slope direction & 0.56 & 0.23 & -0.21 \\
\hline Slope gradient & -0.93 & 0.29 & -0.12 \\
\hline Altitude & -0.92 & 0.36 & -0.16 \\
\hline $\begin{array}{c}\text { The content of } \\
\text { gravel }\end{array}$ & 0.41 & -0.91 & -0.21 \\
\hline $\begin{array}{c}\text { Soil thickness } \\
\text { Rock coverage }\end{array}$ & -0.62 & 0.92 & 0.32 \\
\hline $\begin{array}{c}\text { Variance } \\
\text { contribution }\end{array}$ & 45.72 & -0.68 & 0.16 \\
\hline $\begin{array}{c}\text { Cumulative } \\
\text { variance } \\
\text { contribution }\end{array}$ & 45.72 & 73.01 & 88.97 \\
\hline $\begin{array}{c}\text { Sul } \\
\text { She }\end{array}$ & 28.29 & 15.96 \\
\hline
\end{tabular}




\section{Discussion}

\section{The Spatial Heterogeneity of SOCD in the Small Karst Watershed}

The soil organic carbon pool was the most important carbon pool in the ecosystem; furthermore, the carbon pool has the largest capacity and longest conversion cycle in the terrestrial ecosystem [23]. The average value of the SOCD was $12.11 \mathrm{~kg} \cdot \mathrm{m}^{-2}$ at a depth of $100 \mathrm{~cm}$ in the small karst watershed, which was higher than the national level $\left(10.53 \mathrm{~kg} \cdot \mathrm{m}^{-2}\right)$ [24]. This was because there were inputs of vegetation litter and root exudates, along with the formation and decomposition of humus in certain areas under natural conditions. On the other hand, the soil respiration rate was lower in the karst region, combined with the smaller nutrient absorption of vegetation in soil, leading to a relatively high SOCD [25]. Compared with other basins in neighboring provinces, the SOCD in the small karst watershed was higher than that in the loess hilly region $\left(10.92 \mathrm{~kg} \cdot \mathrm{m}^{-2}\right)$ [26] and close to that in the karst regions in Yunnan, Guizhou, and Guangxi provinces, as calculated by Zhangyong $\left(13.98 \mathrm{~kg} \cdot \mathrm{m}^{-2}\right)$.

Spatial structure and grade are important properties of an ecosystem. Without the spatial structure, the ecosystem has no function [27]. There is universal spatial variation of soil properties, whether at a regional scale or on a middle and small scale. This makes geo-statistical analysis a powerful tool to quantitatively research the above questions. The spatial distribution of SOCD includes two aspects: one is that SOCD changes with the soil thickness in a vertical direction, and the other is that SOCD changes with geographical location in a horizontal direction [28]. There was some degree of spatial heterogeneity of SOCD at different levels of soil within $75 \mathrm{~km}^{2}$ in the small karst watershed. The soil exhibits synthesis with extremely complex patterns and evolution. It is influenced by soil formation factors, including parent material, terrain, climate, and vegetation, along with human disturbances, which decide its complexity and spatial variability. Based on this study, the influencing factors in the small karst watershed were random factors.

Soil organic carbon density was controlled by many factors, such as climate, vegetation, soil properties, and agricultural practices, as well as the interaction between various factors [29]. The karst rocky desertification area was larger; in 2010, the Guizhou rocky desertification area was $36,500 \mathrm{~km}^{2}$ and accounted for $18.79 \%$ of the province's land area. Because of the rocky desertification effects, the results involved a large amount of soil erosion, bare rock, discontinuous soil, and habitat complexity [30]. The structure and distribution of carbonate rock karst in soil were not uniform, the thickness of the soil layer was obviously different, and, ultimately, the formation of the Puding River basin after the village space heterogeneity was extremely high, with complex horizontal characteristics [31]. The proportion of the nugget effects $\mathrm{C}_{0} /\left(\mathrm{C}_{0}+\mathrm{C}_{1}\right)$ in the semi-variogram of SOCD were all higher than $70 \%$ in the small karst watershed, showing up a large random variation. The result showed that the SOCD in the small karst watershed was mainly affected by non-artificial structural factors, including the parent material, terrain, climate, and so on, but was less affected by spatial factors. The spatial pattern of the SOCD was low in the middle and high areas in the small karst watershed. Moreover, soil thickness was not continuous, which made the distribution of SOCD uneven.

The main factors influencing soil organic carbon content in the small karst watershed included the soil carbon content dependence on the dynamic balance between inputs and outputs of organic carbon; the former mainly consists of plant litter and dead roots, whereas the latter mainly comes from the decomposition of organic matter by soil microorganisms [32]. Therefore, all of the factors that affect soil organic carbon accumulation and decomposition affect the distribution of soil organic carbon. In general, soil organic carbon is the overall result of vegetation, climate, soil properties, land use, and various other natural and human factors. The effect of vegetation is mainly exerted through the quality and quantity of litter and the effect of their roots; in cooperation with soil organisms and microorganisms, they form soil organic matter of different quality and quantity, affecting the accumulation and turnover of soil organic carbon [33]. Studies have shown that under the same climate conditions, the type of forest vegetation exerts a significant effect on the yield and decomposition rate of plant litter, which leads to differences in soil organic carbon density among different vegetation types [34]. In this study, we determined that in the small karst watershed, soil organic carbon density in the $20 \mathrm{~cm}$ depth among different vegetation types was as follows: shrub forest $>$ deciduous broad-leaved forest $>$ evergreen broad-leaved forest $>$ evergreen coniferous forest; the density at $100 \mathrm{~cm}$ depth was shrub forest $>$ deciduous broad-leaved forest $>$ evergreen broad-leaved forest $>$ evergreen coniferous forest. This could be explained by the high litter yield and high decomposition rate of litter in the shrub forest, where the organic carbon density was highest.

The soil type reflects the effect of parent material, topography, and hydrothermal conditions, which also lead to a different soil organic carbon density. In a small karst watershed, the soil organic carbon density of different soil types at $20 \mathrm{~cm}$ deep were as follows: black lime soil $>$ yellow lime soil $>$ white sand soil $>$ white large-clay mud $>$ small-clay mud $>$ large-mud field $>$ large-clay mud $>$ yellow-mud field $>$ yellow mud soil; and organic carbon densities at $100 \mathrm{~cm}$ depth were as follows: white largeclay soil $>$ large-clay soil $>$ large-mud field $>$ small-clay soil $>$ yellow mud soil $>$ yellow lime soil $>$ yellow-mud field $>$ white sand soil $>$ black lime soil. Lime soil is a non-zonal soil in subtropical areas of China, which is largely different from yellow, red, and other zonal soils that are highly weathered and form the deep soil layer, whereas limestone breaks into soil very slowly, forming only a shallow soil layer.

A stepwise regression analysis suggested that the soil organic carbon content in the small karst watershed was 
significantly affected by stone grain content, altitude, slope, rate of bare rock, slope position, and depth of soil. Six major factors explained $70.85 \%$ of the variation of the soil organic carbon content in the small karst watershed, suggesting the presence of other influencing factors such as physical and chemical properties of the soil, soil microorganisms, and human activity, which require further analysis. Therefore, vegetation, soil characteristics, topography, human activities, and other biological and non-biological factors should be collectively considered in the estimation of soil carbon storage and in studies of the carbon cycle.

\section{Conclusions}

Soil organic carbon density in the small karst watershed varied among different depths, vegetation types, land uses, and soil types. Organic carbon density was highest in soil at the $20-30 \mathrm{~cm}$ depth $\left(1.5 \mathrm{~kg} . \mathrm{m}^{-2}\right)$, and generally decreased at deeper depths.

The nugget-to-sill ratio $\mathrm{C}_{0} /\left(\mathrm{C}_{0}+\mathrm{C}_{1}\right)$ was larger than $70 \%$ in all layers of this karst watershed, and the organic carbon content in the soil layers was basically higher in the east and lower in the west. The spatial variation of organic carbon content in the surface soil was observed only within a limited range, which gradually decreased from east to west and presented a trend in which the middle segment was low, the surrounding segment was high, the eastern segment was higher, and the southern segment was lowest.

The soil organic carbon content in the small karst watershed was significantly correlated with altitude, soil thickness, stone grain content, slope, and rock exposure rate. Soil thickness, rock bareness, and altitude were the main factors that affected the soil organic carbon content in the small karst watershed; soil thickness contributed the most, which in turn was mainly affected by karst topography.

\section{Acknowledgements}

This work was financially supported by the National Key Basic Research Development Program (grant No. 2013CB956702), the Great Basic Research Fund of Guizhou Province (grant No. QKH-JZ-2014-200203), and the 100 High-Level Innovating Project (grant No. QKHRC-2015-4022).

\section{References}

1. ELEANOR H., GARRY R.W., SILVIA F.B., GERALDINE J. Stability and storage of soil organic carbon in a heavytextured Karst soil from south-eastern Australia. Soil Research. 52, 47, 2014.

2. STEFFENS M., K"OLBL A., K"OGEL-Knabner I. Alteration of soil organic matter pools and aggregation in semi-arid steppe topsoils as driven by organic matter input.
Eur. J. Soil. Sci. 60, 198, 2009.

3. PUGET P., LAL R. Soil organic carbon and nitrogen in a Mollisol in central Ohio as affected by tillage and land use. Soil and Tillage Research. 80 (1-2), 201, 2005

4. YU D.S., ZHANG Z.Q., YANG H., SHI X.Z., TAN M.Z., SUN W.X., WANG H.J. Effect of soil sampling density on detected spatial variability of soil organic carbon in a red soil region of China. Pedosphere. 21 (2), 207, 2011.

5. SAMEREH F., SEYED M.H., SHAMSOLLAH A., ABDOLRASSOUL S. Predicting soil organic carbon density using auxiliary environmental variables in northern Iran. Archives of Agronomy and Soil Science. 62 (3), 375, 2015.

6. TAHAR G.A., NADHEM B.B., MARTIAL B.C. Soil organic carbon density and storage in Tunisia. Global Soil Spatial Information Systems. 1, 2010.

7. LAL R. Soil erosion and the global carbon budget. Environ Int. 29, 437, 2003.

8. LI Z.P., HAN F.X., SU Y., JOHN P. Assessment of soil organic and carbonate carbon storage in China. Geoderma. 138, 119, 2007.

9. LIU Z.T., LIU C.Q., LANG Y.C., HU D. Dissolved organic carbon and its carbon isotope compositions in hill slope soils of the karst area of southwest China: Implications for carbon dynamics in limestone soil. Geochemical Journal. 48, 277, 2014.

10. MAO D.H., WANG Z.M., LI L., MIAO Z.H., MA W.H., SONG C.C., REN C.Y., JIA M.M. Soil organic carbon in the Sanjiang Plain of China: storage, distribution and controlling factors. Biogeosciences. 12, 1635, 2015.

11. QI Y.B., DARILEK J.L., HUANG B., ZHAO Y.C., SUN W., GU Z.Q. Evaluating soil quality indices in an agricultural region of Jiangsu Province, China. Geoderma. 149, 325, 2009.

12. LIU Y.G., LIU C.C., WANG S.J, GUO K., YANG J., ZHANG X.S., LI G.Q. Organic carbon storage in four ecosystem types in the Karst Region of southwestern China. Plos One. 8 (2), 56443, 2013.

13. LIU Z.H., DREYBRODT W, WANG H.J. A possible important $\mathrm{CO}_{2}$ sink by the global water cycle. Chinese Science Bulletin. 53 (3), 402, 2008.

14. HUANG Q.H., CAI Y.L., XING X.S. Rocky desertification, antidesertification, and sustainable development in the karst mountain region of Southwest China. Ambio A Journal of the Human Environment. 37 (5), 390, 2008.

15. ORHAN D., MUSTAFA S., FERHAT T. Effects of soil types and land use - land cover on soil organic carbon density at Madendere watershed. Eurasian. J Soil Sci. 4 (2), 82, 2015.

16. 16. of soilorganic carbon pool with the process of natural restoration of Karst forest vegetation. Acta Pedologica Sinica. 50 (2), 306, 2013 [In Chinese].

17. KERRY R., OLIVER M.A. Average variograms to guide soil sampling. International Journal of Applied Earth Observation and Geoinformation, 5, 307, 2004.

18. HE Y., WANG F., TIAN P., MU X.M., GAO P., ZHAO G.J., WU Y.P. Impact Assessment of Human Activities on Runoff and Sediment of Beiluo River in the Yellow River Based on Paired Years of Similar Climate. Pol. J. Environ. Stud. 25 (1), 126, 2016.

19. BERGSTROM D.W., MONREAL C.M., MILLETTE J.A., KING D.J. Spatial Dependence of Soil Enzyme Activities along a Slope. Soil Sci. Soc. Am. J. 62, 13041998.

20. POST W.M., PENG T.H., EMANUEL W.R, KING A.W, DALE V.H, DEANGELIS D.L. The global carbon cycle. American Scientist.78, 313, 1990.

21. HAILU K.A., ANDREAS K. Predicting the spatial distribution of soil erodibility factor using USLE nomograph 
in an agricultural watershed, Ethiopia. International Soil \& Water Conservation Research, 3 (4), 287, 2015.

22. STACEY K.F., LARK R.M., WHITMORE A.P., MILNE A.E. Using a process model and regression kriging to improve predictions of nitrous oxide emissions from soil. Geoderma. 135 (11), 113, 2006.

23. LI Y. Can the spatial prediction of soil organic matter contents at various sampling scales be improved by using regression kriging with auxiliary information. Geoderm. 159, 72, 2010.

24. MI N., WANG S.Q., LIU J.Y., YU G.R., ZHANG W.J., JOBBÁGY E.B. Soil inorganic carbon storage pattern in China. Global Change Biology. 14 (10), $2380,2008$.

25. TANG F.K., CUI M., LU Q., ZHOU J.X., GUO H.Y., WANG Z.Y. Soil Respiration and Its Sensitivity to Temperature Under Different Vegetation Types in Typical Karst Gorge Area. Bulletin of Soil and Water Conservation. 36 (1), 61, 2016 [In Chinese].

26. CHANG R.Y., FU B.J., LIU G.H., WANG S., YAO X.L. The effects of afforestation on soil organic and inorganic carbon: A case study of the Loess Plateau of China. Catena. 95 (3), 145, 2012.

27. YU D.S., ZHANG Z.Q., YANG H., SHI XZ., TAN M.Z., SUN W.X., WANG H.J. Effect of soil sampling density on detected spatial variability of soil organic carbon in a red soil region of China. Pedosphere. 21 (2), 207, 2011.
28. QI Y.B., DARILEK J.L., HUANG B., ZHAO Y.C., SUN W., GU Z.Q. Evaluating soil quality indices in an agricultural region of Jiangsu Province, China. Geoderma. 149, 325, 2009.

29. SUTFIN N.A., WOHL E.E., DWIRE K.A. Banking carbon: a review of organic carbon storage and physical factors influencing retention in floodplains and riparian ecosystems. Earth Surf Process Landf. 41, 60, 2016.

30. HAN G.L., LI F.S., TANG Y. Variations in soil organic carbon contents and isotopic compositions under different land uses in a typical karst area in Southwest China .Geochemical Journal. 49, 63, 2015.

31. WANG D.J., SHEN Y.X., LI Y.H., HUANG J. Rock Outcrops Redistribute Organic Carbon and Nutrients to Nearby Soil Patches in Three Karst Ecosystems in SW China. Plos One. 11 (8), 15, 2016.

32. SELMA Y.K. Effects of afforestation on soil organic carbon and other soil properties. Catena. 123 (10), 62, 2014.

33. ZHANG W, CHEN H.S, WANG K.L, SU Y.R, ZHANG J.G., YI A.J. The heterogeneity and its influencing factors of soil nutrients in peakcluster depression areas of karst region. Agric Sci China. 6, 322, 2007.

34. CI E., MAHDI M.A., WANG L., DING C.H., XIE D. Soil Organic Carbon Mineralization as Affected by Cyclical Temperature Fluctuations in a Karst Region of Southwestern China. Pedosphere. 25 (4), 523, 2015. 